\title{
Insulinoma in a Patient with Non-Insulin-Dependent Diabetes Mellitus
}

\author{
AKIHIRO SAKURAI, TORU AIZAWA, MASAFUmi KATAKURA**, YoshIHIKo SATO, \\ GENGO KANEKO*, KUNIO YOSHIZAWA**, AND KIYOSHI HASHIZUME \\ Department of Geriatrics, Endocrinology and Metabolism, and *Department of Surgery II, Shinshu University \\ School of Medicine, Matsumoto 390, and **Asama General Hospital, Saku 385, Japan
}

\begin{abstract}
Insulinoma in a patient with pre-existing diabetes is exceedingly rare. Only a small number of well-documented cases have been reported in the world during the last 40 years. We describe a case with non-insulin-dependent diabetes mellitus who after seven years of sulfonylurea treatment experienced recurrent episodes of hypoglycemia. Endogenous hyperinsulinism was found and radiographical examination and transhepatic venous sampling confirmed an insulin secreting pancreatic tumor. After surgical excision of the tumor, patient was relieved from hypoglycemic attacks but required to initiate insulin injection for the treatment of hyperglycemia.
\end{abstract}

Key words: Insulinoma, Diabetes, Pancreas tumor

(Endocrine Journal 44: 473-477, 1997)

INSULINOMA, a functioning neoplasm arising from $\beta$ cells of the endocrine pancreas, is an uncommon clinical disorder [1]. On the other hand, diabetes is common metabolic disorder of which functional disorder of $\beta$ cells plays significant part of its etiology. The possible relationship between diabetes and the natural history of insulinoma is unknown. Earlier reports suggested that chronic therapy of diabetes with sulfonylurea, or insulin resistance due to long-standing diabetes, might induce anatomic evidence of hyperplasia and eventual adenomatous transformation of the $\beta$ cells [2-4]. Experimentally, nicotinamide, which prevents the development of streptozotocininduced diabetes $[5,6]$, induced insulinomas when administered together with streptozotocin [7]. However, those observations have not been

Received: December 24, 1996

Accepted: March 5, 1997

Correspondence to: Dr. Akihiro SAKURAI, Department of Geriatrics, Endocrinology and Metabolism, Shinshu University School of Medicine, 3-1-1 Asahi, Matsumoto 390, Japan supported by clinical experience, rather concurrence of insulinoma and diabetes is exceedingly rare than expected from incidence of two disorders. As far as we are aware, only a few case reports in patients with non-insulin dependent diabetes mellitus (NIDDM) [8-16] and one report in a patient with insulin dependent diabetes mellitus (IDDM) [17] have been made. Furthermore, because of the lack of specific radioimmunoassay for insulin [8-10] and detailed description for associated conditions such as liver cirrhosis [10] or renal failure $[9,11]$, it is difficult to completely rule out hypoglycemia not due to insulinoma in some of the earlier reports. Also, primary pathological findings were diffuse islet cell hyperplasia rather than islet cell adenoma in some cases [11, 12]. In fact, preoperative diagnosis and localization of the tumor could be made only in recent cases [15-17]. We encountered a case of insulinoma occurred in a patient with NIDDM. Hypersecretion of insulin from the tumor was preoperatively confirmed by venous sampling. 


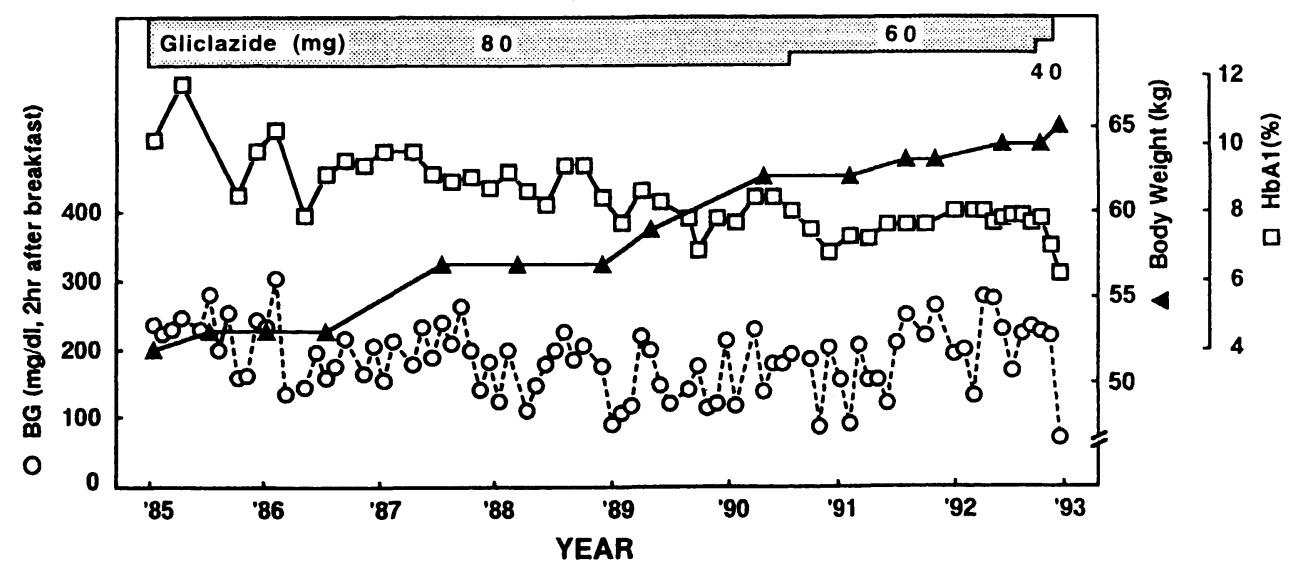

Fig. 1. Clinical course of the patient. Normal range of $\mathrm{Hb}_{\mathrm{A} 1}$ is 5.5-8.0\%. BG, blood glucose. 100 $\mathrm{mg} / \mathrm{d} l \mathrm{BG}=5.55 \mathrm{mmol} / l \mathrm{BG}$.

\section{Case Report}

A 70-year-old male was referred to Shinshu University Hospital because of frequent hypoglycemic attacks. He was discovered having positive urine glucose at the age of 46 . Diagnosis of diabetes was subsequently made and treatment with gliclazide was instituted in 1985 when he was 62 years old (Fig. 1). Until 1990, he had been treated with gliclazide ( $80 \mathrm{mg} /$ day) and his hemoglobin A1 level gradually lowered. Note that this happened despite increase in the body weight from $52 \mathrm{~kg}$ (body mass index; $22.5 \mathrm{~kg} / \mathrm{m}^{2}$ ) to $62 \mathrm{~kg}$ $\left(27.6 \mathrm{~kg} / \mathrm{m}^{2}\right)$ during the same period. In 1990, he experienced the initial hypoglycemic attack before lunch, and the dose of gliclazide was reduced to $60 \mathrm{mg} /$ day. In 1992, he experienced recurrent preprandial hypoglycemic attacks before almost every meal, progressive forgetfulness and lethargy. Dose of gliclazide was further reduced and the medication was finally discontinued. In December, 1992, 3 weeks after discontinuation of gliclazide, his fasting plasma glucose was $3.1 \mathrm{mmol} / \mathrm{l}(55 \mathrm{mg} /$ $\mathrm{d} l$ ) and plasma insulin (IRI) and C-peptide levels were $264 \mathrm{pmol} / l(44 \mu \mathrm{U} / \mu l)$ and $5.1 \mathrm{ng} / \mathrm{ml}$, respectively. Hypoglycemia and endogenous hyperinsulinism was thus confirmed. Hemoglobin A1c level was $4.1 \%$ (normal: 3.5-5.5\%).

On admission in January, 1993, the body weight was $65.0 \mathrm{~kg}$, and the height was $150 \mathrm{~cm}$ (body mass index; $28.9 \mathrm{~kg} / \mathrm{m}^{2}$ ). Results of routine laboratory tests including blood chemistry, hemogram and

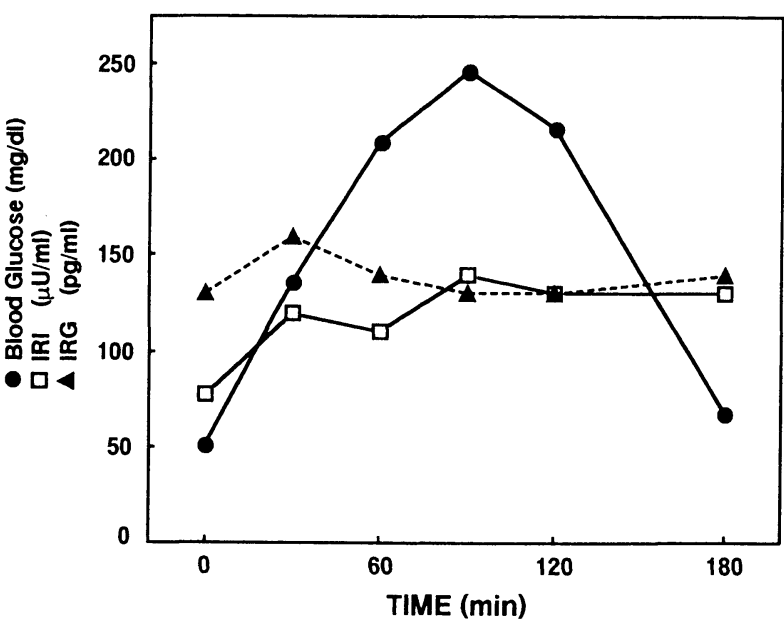

Fig. 2. Results of $75 \mathrm{~g}$ oral glucose tolerance test. $100 \mu \mathrm{U} /$ $\mathrm{m} l \mathrm{IRI}=718 \mathrm{pmol} / l$ IRI. IRG, glucagon

serology were unremarkable. Function of the pituitary, thyroid and adrenal glands were normal. Urinary C-peptide was elevated to $164 \mu \mathrm{g}$ /day. Anti-insulin antibody was negative. As shown in Fig. 2, $75 \mathrm{~g}$ oral glucose tolerance test showed a diabetic pattern with plasma glucose being 12.1 $\mathrm{mmol} / \mathrm{l}(217 \mathrm{mg} / \mathrm{d} l)$ at $120 \mathrm{~min}$ despite high level of plasma IRI. Computed tomography and digital subtraction angiography revealed a single hypervascular mass $(25 \times 25 \mathrm{~mm})$ at the body of the pancreas (Fig. 3). A sharp step-up of IRI level immediately distal to the tumor in splenic vein was noted by the percutaneous transhepatic venous sampling (Fig. 4). 


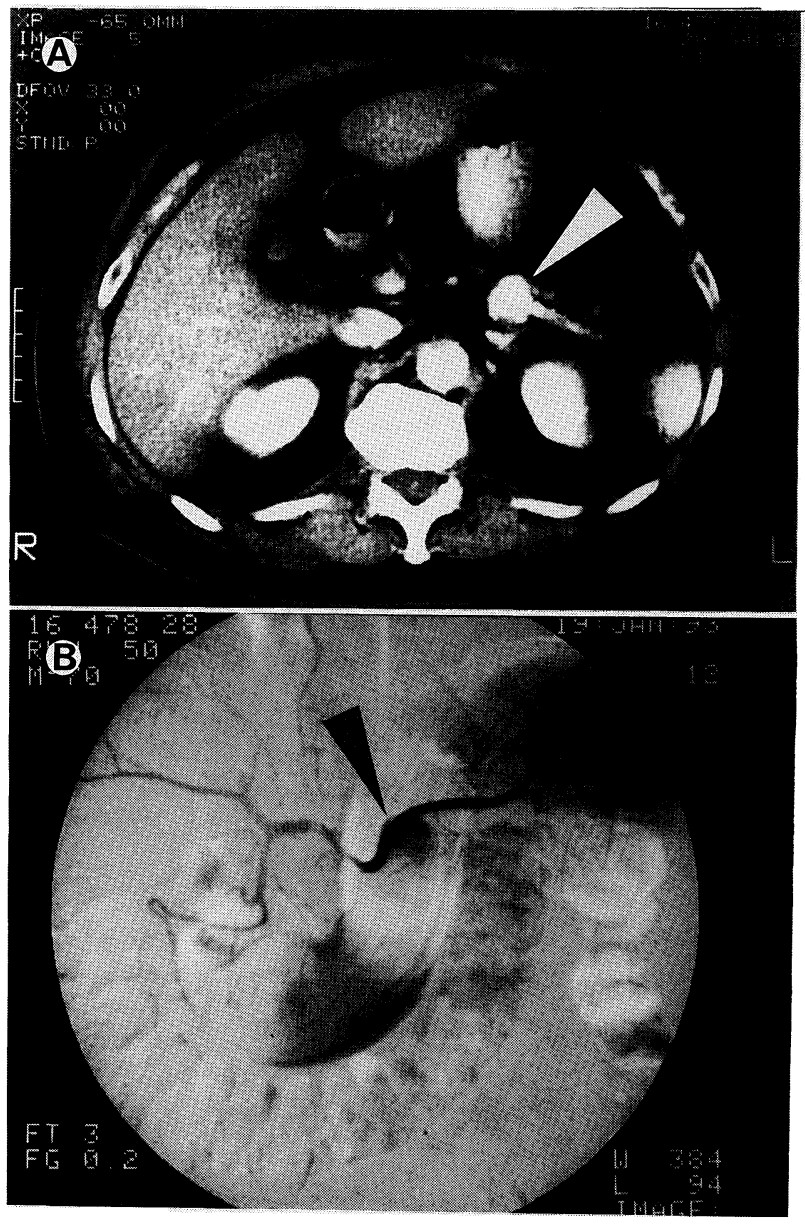

Fig. 3. Imaging of the islet cell tumor. Computed tomography (A), and digital subtraction angiography (B), reveals a hypervascular mass at the body of the pancreas (arrowhead).

Diagnosis of insulin-producing pancreatic tumor in a patient with NIDDM was thus made, and enucleation of the tumor was performed in March, 1993. Histopathological examination confirmed an islet cell adenoma, and with immunostaining, tumor was positive for insulin and chromogranin A, but negative for glucagon and somatostatin.

After surgery, urinary C-peptide excretion decreased to $24.4 \mu \mathrm{g} / \mathrm{day}$, and insulin injection was started for the treatment of hyperglycemia. In September, 1996, hemoglobin A1c level was 8.6\% with $42 \mathrm{U} /$ day of insulin injection. The body weight had been $56-57 \mathrm{~kg}$ after operation.

\section{Discussion}

Etiology of insulinoma has been mostly unknown. Because the incidence of insulinoma in general population is about $4 /$ million/year [1] and the prevalence of NIDDM in adults is $5-10 \%$ in industrial countries [18], insulinoma in a patient with NIDDM should have been observed more commonly in those countries. However, coincidence of these two disorders are exceedingly rare as to warrant individual case reports. The incidence and prevalence of insulinoma in Japanese is unknown. Among 443 cases reported from 1976 to 1990, coincidence of diabetes was noted in only one case with malignant insulinoma, of which the detail was not described [19]. Since the prevalence of NIDDM in Japan is similar to that in other industrial countries [18], it seems that, regardless of ethnic origin, the presence of diabetes prevents occurrence of insulinoma and/or manifestation of clinical symptoms caused by insulinoma. Several possibilities could be considered for this negative correlation between two disorders. The number of $\beta$ cells is decreased in patients with IDDM and non-obese NIDDM $[20,21]$, which means the decrease of the cellular basis for tumor formation. However in the majority of diabetic patients, who are usually obese and non-insulin dependent, the number of $\beta$ cells may not be decreased. It is also possible that $\beta$ cell regeneration capability is depressed in patients with diabetes leading to low incidence of insulinoma. Alternatively, insulinoma may occur in diabetic patients with the same incidence as in non-diabetic subjects, but not readily be diagnosed because of insulin resistance [16]. In our case, gradual increase in body weight (Fig. 1) suggests that hyperinsulinism, probably due to insulinoma, had existed for long time. This may have caused insulin resistance, thus preventing clinical symptoms to appear until hyperinsulinism becomes severe. Insulin resistance in our case was confirmed by hyperinsulinemic-isoglycemic clamp method (data not shown) [22]. Also, hypoglycemia due to insulinoma occurred in diabetic patients could be mistakenly considered as the over-dose of hypoglycemic agents or insulin, either iatrogenic or factitious. Consequently, the delay of diagnosis may occur for milder cases: iatrogenic or factitious hyperinsulinism could easily be distinguished from insulinoma by measuring plasma C-peptide 


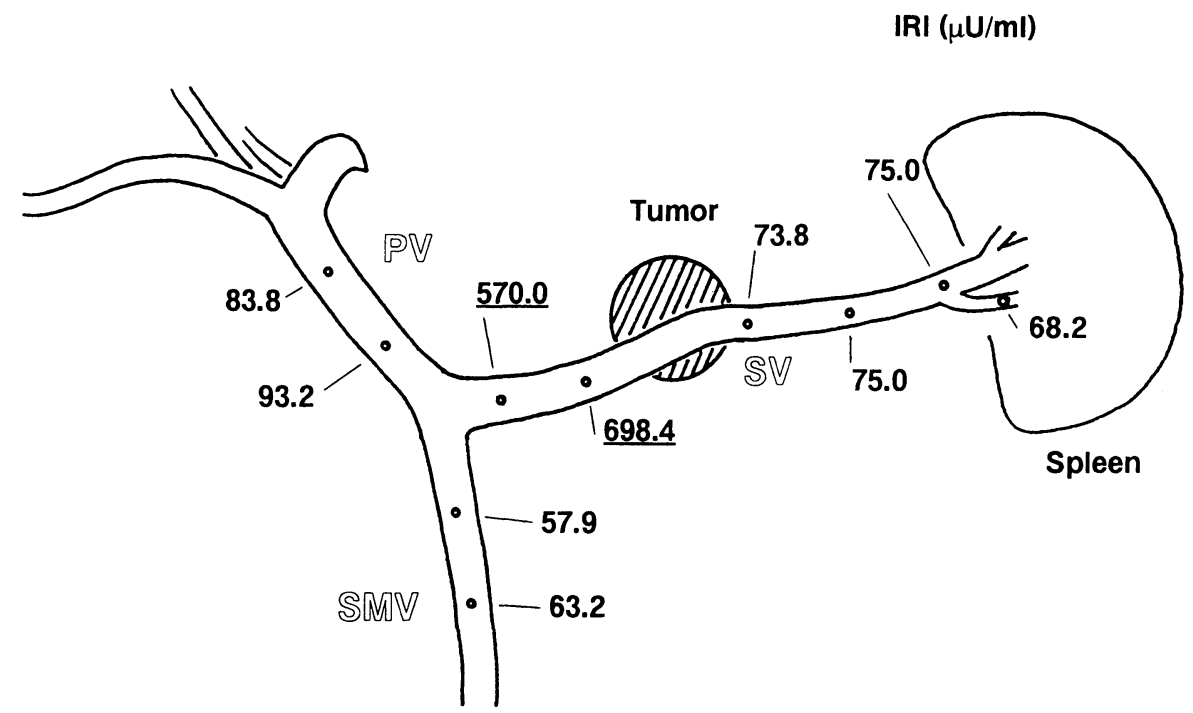

Fig. 4. Results of the percutaneous transhepatic venous sampling. IRI levels at each point in the veins are schematically shown. $100 \mu \mathrm{U} / \mathrm{ml} \mathrm{IRI}=718 \mathrm{pmol} / l \mathrm{IRI}$. SMV, superior mesenteric vein; SV, splenic vein; $P V$, portal vein.

concentration.

Recent progress in understanding of the molecular mechanism of insulin secretion and tumorigenesis in islet cells should be helpful to elucidate the preventive effect of diabetes on the formation of insulinoma.

\section{References}

1. Service FJ, McMahon MM, O'Brien PC, Ballard DJ (1991) Functioning insulinoma-incidence, recurrence, and long-term survival of patients: $\mathrm{A}$ 60-year study. Mayo Clin Proc 66: 711-719.

2. Bloodworth JMB Jr (1963) Morphologic changes associated with sulfonylurea therapy. Metabolism 12: 287-301.

3. Balodimos MC, Marble A, Rippey JH, Legg MA, Kuwabara T, Gleason RE (1968) Pathological findings after long-term sulfonylurea therapy. Diabetes 17: 503-508.

4. Like AA, Steinke J, Jones EE, Cahill GF Jr (1965) Pancreatic studies in mice with spontaneous diabetes mellitus. Am J Pathol 46: 621-644.

5. Schein P, Cooney D, Vernon L (1967) The use of nicotinamide to modify the toxicity of streptozotocin diabetes without loss of antitumor activity. Cancer Res 27: 2324-2332.

6. Ganda OP, Day JL, Soeldner JS, Connon JJ, Gleason RE (1976) Studies on streptozotocin diabetes. Diabetes 27: 595-603.

7. Volk BW, Wellmann KF, Brancato P (1973) Live structure of rat islet cell tumors induced streptozotocin and nicotinamide. Diabetologia 10: 37-
44.

8. van der Sar A, Bosschieter E, Hugenholtz MJ, van der Hoeven L (1956) Spontaneous hypoglycaemic attacks due to an insulinoma in a diabetic. Doc Med Georgraph Trop 8: 85-95.

9. Haarstad J (1957) Hormone-producing insuloma in diabetes mellitus. Acta Med Scand 159: 247-249.

10. Gittler RD, Zucker G, Eisinger R, Stoller N (1958) Amelioration of diabetes mellitus by an insulinoma. $N$ Engl J Med 258: 932-935.

11. Knight PO (1967) Insulinoma and generalized islet cell hyperplasia in a patient with diabetes mellitus. South Med J 60: 119-123.

12. Sandler R, Horwitz DL, Rubenstein AH, Kuzuya $H$ (1975) Hypoglycemia and endogenous hyperinsulinism complicating diabetes mellitus. Am J Med 59: 730-736.

13. Atkinson $\mathrm{AB}$, Buchanan $\mathrm{KD}$, Carson DJ, Kennedy T, O'Hare MMT, Sloan JM, Hadden DR (1978) Insulinoma (apud cell carcinoma) in a diabetic. Brit Med J 2: 1397-1398.

14. Heik SCW, Klöppel G, Krone W, Iben G, Priebe K, Kühnau J (1988) Hypoglycaemia caused by an insulinoma in a type II diabetic. Dtsch Med Wschr 
113: 1714-1717 (In German).

15. Kane LA, Grant CS, Nippoldt TB, Service FJ (1993) Insulinoma in a patient with NIDDM. Diabetes Care 16: 1298-1300.

16. Grunberger G (1993) Insulin resistance in a case of coexisting insulinoma and type 2 diabetes. Acta Diabetol 30: 243-250.

17. Svatberg J, Stridsberg M, Wilander E, Andersson DE, Eriksson B (1996) Tumor-induced hypoglycaemia in a patient with insulin-dependent diabetes mellitus. $J$ Int Med 239: 181-185.

18. Warram JH, Rich SS, Krolewski AS (1994) Epidemiology and Genetics of Diabetes Mellitus. In: Kahn CR, Weir CC (eds) Joslin's Diabetes Mellitus. 13th ed, Philadelphia: Lea \& Febiger: 201215.
19. Ishii $H$, Ito $T$, Moriya $S$, Horie $Y$, Tsuchiya $M$ (1993) Insulinoma - a statistical review of 443 cases in Japan. Nippon Rinsho (Jpn J Clin Med) 51 Suppl: 199206 (In Japanese).

20. Weir GC (1982) Non-insulin-dependent diabetes mellitus: Interplay between $\beta$-cell inadequacy and insulin resistance. Am J Med 73: 461-464.

21. Unger RH, Grundy S (1985) Hyperglycemia as an inducer as well as a consequence of impaired islet cell function and insulin resistance: Implications for the management of diabetes. Diabetologia 28: 119121.

22. Bergman RN, Finegood DT, Ader M (1985) Assessment of insulin sensitivity in vivo. Endocr Rev 6: 45-86. 